\title{
PENGARUH FEE AUDIT, AUDIT TENURE DAN ROTASI AUDIT TERHADAP KUALITAS AUDIT (STUDI EMPIRIS PADA PERUSAHAAN MANUFAKTUR SUB SEKTOR MAKANAN DAN MINUMAN YANG TERDAFTAR DI BURSA EFEK INDONESIA PERIODE TAHUN 2015-2019)
}

\author{
Adolpino Nainggolan, SE, M. Ak ${ }^{1)}$ \\ Alfian 2) \\ adolpino_nainggolan@yahoo.co.id, palingaialfian@gmail.com \\ Universitas Satya Negara Indonesia
}

\begin{abstract}
ABSTRAK
Tujuan penelitian ini adalah untuk mengetahui pengaruh fee audit, audit tenure dan rotasi audit terhadap kualitas audit. Populasinya adalah perusahaan manufaktur sub sektor makanan dan minuman yang terdaftar di Bursa Efek Indonesia (BE) periode tahun 2015-2019. Metode pengambilan sampel adalah Purposive Sampling. Teknik analisis yang digunakan dalam penelitian ini adalah analisis regresi logistik. Hasil penelitian secara parsial variabel fee audit berpengaruh signifikan terhadap kualitas audit, sedangkan variabel audit tenur dan rotasi audit tidak berpengaruh terhadap kualitas audit. Secara simultan variabel fee audit, audit tenure dan rotasi audit berpengaruh terhadap kualitas audit sebesar, 69,1\% sedangkan sisanya sebesar 30,9\% dipengaruhi oleh variabel lainnya yang tidak termasuk dalam penelitian ini.
\end{abstract}

Kata Kunci : Fee Audit, Audit Tenure dan Rotasi Audit terhadap Kualitas Audit

\section{PENDAHULUAN}

Perusahaan yang terdaftar di Bursa Efek Indonesia (BEI), laporan keuangannya setiap akhir tahun wajib di audit oleh auditor independen dalam hal ini Kantor Akuntan Publik (KAP), agar Informasi yang tersaji dalam laporan keuangan dapat dipercaya sebagai dasar pengambilan keputusan bagi para pemangku kepentingan khususnya untuk pemegang saham.

Guna menjaga kepercayaan pengguna laporan keuangan auditan, auditor independen harus memperhatikan kualitas audit yang dihasilkannya. Dari sudut pandang auditor, audit dianggap berkualitas apabila auditor menjalankan audit sesuai dengan standar audit yang berlaku umum, meliputi mutu professional (professional qualities) auditor independen, pertimbangan (judgment) yang digunakan dalam pelaksanaan audit dan penyusunan laporan auditor. Dalam pelaksanaan audit, seorang auditor harus mempunyai kemampuan teknikal dari auditor yang terpresentasi dalam pengalaman maupun profesi dan kualitas auditor dalam menjaga sikap mentalnya (independensi) supaya mampu menciptakan audit yang berkualitas (Hartadi 2012). Kualitas Audit dapat dipengaruhi oleh berbagai faktor, beberapa diantaranya adalah faktor Fee Audit, Audit Tenure dan Rotasi Audit. 
Penelitian ini diasumsikan bahwa auditor yang berkualitas lebih tinggi akan mengenakan fee audit yang lebih tinggi pula, karena auditor yang berkualitas akan mencerminkan informasi-informasi yang dimiliki oleh pemilik perusahaan (Ian, 2013), karena auditor yang berkualitas akan memberikan kepercayaan kepada calon investor tentang estimasi aliran kas masa depan dari perusahaan. Hal ini menunjukkan bahwa jika pilihan pemilik akan auditor yang berkualitas, maka makin tinggi harga saham perusahaan di pasar perdana (Ian, 2013)

Audit tenure juga dapat mempengaruhi kualitas audit dilihat dari jangka waktu perikatan auditor dengan klien. Audit tenure yang panjang dapat dianggap auditor sebagai pendapatan, namun tenure yang panjang juga dapat menyebabkan adanya hubungan emosional antara klien dengan auditor sehingga dapat menurunkan independensi auditor yang dapat mempengaruhi kualitas audit (Margi Kurniasih dan Abdul Rohman, 2014).

Peraturan rotasi audit dibuat dengan tujuan untuk meningkatkan kualitas audit berdasarkan pada asumsi bahwa rotasi audit akan mengurangi adanya hubungan emosional antara klien dengan auditor yang disebabkan oleh lamanya hubungan antara auditor dengan kliennya, sehingga mengurangi independensi auditor. Oleh karena itu, diberlakukan adanya rotasi yang bersifat mandatory supaya mengurangi hubungan spesial yang terjalin antara klien dengan auditor (Margi Kurniasih dan Abdul Rohman, 2014).

Beberapa penelitian telah dilakukan oleh peneliti sebelumnya, namun hasilnya masih menunjukkan ketidak konsistenan. Hasil penelitian yang dilakukan oleh I Gusti Ngurah Indra Pramaswaradana dan Ida Bagus Putra Astika (2017), Maisyarah Salsabila (2018), dan Yuha Nadhirah Qintharah (2020) fee audit berpengaruh terhadap kualitas audit, sedangkan penelitian Stefani Fransiska Lele Biri (2019) dan Tri Agustini dan Dian Lestari Siregar (2020) fee audit tidak berpengaruh terhadap kualitas audit.

Hasil penelitian I Gusti Ngurah Indra Pramaswaradana dan Ida Bagus Putra Astika (2017) dan Ahmad Buchori dan Harry Budiantoro (2019) audit tenur berpengaruh terhadap kualitas audit, sedangkan penelitian Yunike Nadya dan Pitaloka Santoso (2019), Tri Agustini dan Dian Lestari Siregar (2020) audit tenur tidak berpengaruh terhadap kualitas audit.

Hasil penelitian Ahmad Buchori dan Harry Budiantoro (2019) rotasi audit berpengaruh terhadap kualitas audit, sedangkan penelitian I Gusti Ngurah Indra Pramaswaradana dan Ida Bagus Putra Astika (2017), Maisyarah Salsabila (2018), Tri Agustini dan Dian Lestari Siregar (2020), dan Yuha Nadhirah Qintharah (2020) rotasi audit tidak berpengaruh terhadap kualitas audit.

Berdasarkan uraian perbedaaan hasil penelitian di atas, maka membuat peneliti tertarik untuk melakukan penelitian selanjutnya tentang pengaruh Fee Audit, Audit Tenure dan Rotasi Audit terhadap Kualitas Audit.

\section{LANDASAN TEORI}

\section{Kualitas Audit}

Rendal J. Elder, Mark S. Basley, Alvin A. Arens dalam Amir Abadi (2011:47) mendefinisikan kualitas audit adalah suatu proses untuk memastikan bahwa standar 
auditing yang berlaku umum diikuti dalam setiap audit, KAP mengikuti prosedur pengendalian kualitas audit khusus yang membantu memenuhi standar-stamdar itu secara konsisten pada setiap penugasannya.

Adapun menurut Malem Ukur Tarigan dan Primsa Bangun Susanti (2013) menggambarkan bahwa: kualitas audit adalah pelaksanaan audit yang dilakukan sesuai standar sehingga auditor mampu mengungkapkan dan melaporkan apabila terjadi pelanggaran yang dilakukan klien, standar yang mengatur pelaksanaan audit di Indonesia adalah Standar Profesional Akuntan Publik.

\section{Fee Audit}

Menurut Agoes Sukrisno (2014) komisi audit adalah imbalan dalam bentuk uang atau bentuk lainnya yang diberikan kepada atau diterima oleh auditor atau pihak lain untuk memperoleh perikatan dari klien atau pihak lain.

Fee Audit ditetapkan ketika sudah terjadi kontrak antara auditor dengan klien berdasarkan kesepakatan dan biasanya ditentukan sebelum memulai proses audit (Margih Kurniasih \& Rohman, 2014).

Berdasarkan Surat Keputusan Ketua Umum Institut Akuntan Publik Indonesia Nomor : KEP.024/IAPI/VII/2008 tentang kebijakan penentuan fee audit yaitu dalam menetapkan imbal jasa (fee) audit, Akuntan Publik harus mempertimbangkan hal-hal berikut : kebutuhan klien, tugas dan tanggung jawab menurut hukum (statutory duties); independensi; tingkat keahlian (levels of expertise) dan tanggung jawab yang melekat pada pekerjaan yang dilakukan, serta tingkat kompleksitas pekerjaan; banyak waktu yang diperlukan dan secara efektif digunakan oleh Akuntan Publik dan stafnya untuk menyelesaikan pekerjaan; dan basis penetapan fee yang disepakati.

\section{Audit Tenure}

Tenure adalah lamanya masa perikatan auditor dengan klien dalam memberikan jasa audit yang telah disepakati. Lama atau singkatnya tenure menjadi perdebatan karena tenure dapat berdampak pada kinerja auditor pada perusahaan klien seperti hubungan emosional auditor dengan klien, indepedensi, fee, dan lainlain (Nuratama, 2011).

Di Indonesia peraturan audit tenure telah diatur didalam Peratuan Pemerintah (PP) Nomor 20/2015 Pasal 11. Peraturan ini menjelaskan bahwa pemberian jasa audit umum atas laporan keuangan dari suatu entitas dilakukan oleh KAP paling lama untuk 5 tahun buku berturut-turut. Auditor dapat menerima kembali penugasan audit untuk klien tersebut setelah 2 tahun buku tidak memberikan jasa audit umum atas laporan keuangan klien tersebut.

\section{Rotasi Audit}

Rotasi audit merupakan pergantian akuntan publik dimana akuntan publik di Indonesia hanya dapat mengaudit laporan keuangan perusahaan maksimal 3 tahun berturut-turut (Andriani dan Nursiam, 2018).

Pergantian akuntan publik dapat dibagi menjadi 2 yaitu pergantian auditor yang terjadi regulasi pemerintah yang mengikat (mandatory) dan pergantian auditor yang terjadi dikarenakan alasan lain diluar regulasi (voluntary) dan pergantian auditor secara sukarela dilakukan apabila klien mengganti auditor ketika tidak ada peraturan yang mewajibkan melakukan pergantian auditor 
Ketentuan terkait peraturan rotasi audit dikeluarkan oleh BAPEPAM-LK melalui Keputusan Ketua Bapepam dan LK Nomor KEP-310/BL/2008 tanggal 1 Agustus 2008 yang menyatakan bahwa Kantor Akuntan Publik dan Akuntan Publik dapat menerima penugasan audit kembali untuk klien yang sama setelah 1 (satu) tahun buku tidak mengaudit klien tersebut. Peraturan-peraturan terkait rotasi audit tersebut dibuat dengan tujuan untuk meningkatkan kualitas audit dan menjaga independensi auditor (Siregar et al,2012).

\section{METODE PENELITIAN}

\section{Desain Penelitian}

Desain penelitian yang dilakukan adalah Penelitian Kausal (Causal Research). Penelitian kausal adalah penelitian yang bersifat sebab akibat. Digunakan untuk mengetahui pengaruh antara satu atau lebih variabel bebas (Independent Variable) terhadap variabel terikat (Dependent Variable).

\section{Populasi dan Sampel}

Populasi penelitian ini adalah perusahaan go public yang terdaftar di Bursa Efek Indonesia (BEI) dibidang manufaktur sub sektor makanan dan minuman periode periode 2015-2019. Pengambilan sampel menggunakan purposive sampling, Metode purposive sampling adalah teknik penentuan sampel dengan pertimbangan beberapa kriteria tertentu (Sugiyono, 2017:124). Proses pemilihan sampel adalah sebagai berikut:

Tabel 1

Jumlah Sampel

\begin{tabular}{|c|l|c|}
\hline No. & \multicolumn{1}{|c|}{ Kriteria } & $\begin{array}{c}\text { Jumlah } \\
\text { Perusahaan }\end{array}$ \\
\hline 1 & $\begin{array}{l}\text { Perusahaan manufaktur sub sektor makanan dan } \\
\text { minuman yang terdaftar di BEI periode tahun 2015 sampai } \\
\text { dengan 2019. }\end{array}$ & 28 \\
\hline 2 & $\begin{array}{l}\text { Perusahaan yang tidak mencantumkan akun professional } \\
\text { fees dalam laporan keuangan tahunan }\end{array}$ & $(11)$ \\
\hline 3 & $\begin{array}{l}\text { Perusahaan manufaktur sub sektor food and beverages yang } \\
\text { terdaftar yang tidak menyajikan laporan keuangan yang } \\
\text { telah diaudit yang tidak memiliki data lengkap sesuai } \\
\text { dengan kriteria penarikan sampel }\end{array}$ & $(8)$ \\
\hline 4 & $\begin{array}{l}\text { Jumlah Sampel Perusahaan } \\
\text { Tahun Penelitian }\end{array}$ & 5 \\
\hline 6 & Jumlah Sampel Data Selama Tahun Penelitian & 45 \\
\hline
\end{tabular}

Sumber : Data diolah

\section{Teknik Pengumpulan Data}

Penelitian ini termasuk dalam penelitian kuantitatif dengan menggunakan data sekunder berupa laporan keuangan sebagai sumber data. Data sekunder yang diambil dalam penelitian ini adalah laporan keuangan 
perusahaan manufaktur yang terdaftar di Bursa Efek Indonesia (BEI) yang telah diudit oleh Kantor Akuntan Publik (KAP). Penggunaan laporan keuangan dalam penelitian ini adalah untuk mengukur pengaruh fee audit, audit tenure dan rotasi audit terhadap kualitas audit.

\section{Operasional Variabel dan Skala pengukuran Variabel dependen}

Variabel dependen dalam penelitian ini adalah kualitas audit. Kualitas Audit diukur dengan menggunakan dummy. Perusahaan yang laporan keuangannya diaudit oleh KAP The Big Four diberi kode 1 dan diaudit oleh KAP Non The Big Four diberi kode 0 (Anton 2012).

\section{Variabel Independen}

\section{a Fee Audit}

Fee Audit diukur diukur dengan menggunakan skala rasio dari data akun professional fees yaitu perusahaan yang mencantumkan data tersebut di dalam annual report. Dalam penelitian ini fee audit diproksikan dengan menggunakan logaritma natural (Ln) fee Audit. Penggunaan logaritma natural (Ln) untuk mengurangi digit data terlalu besar akan tetapi tidak mengurangi nilai yang sebenarnya.

\section{b. Audit Tenure}

$$
\text { Ukuran Perusahaan= Ln Fee Audit }
$$

Audit tenure diukur dengan menghitung tahun dimana KAP yang sama telah melakukan perikatan dengan auditee. Audit tenure memiliki nilai maksimum 5 tahun sebagaimana telah diatur dalam Peraturan Pemerintah Republik Indonesia Nomor 20/2015 Pasal 11 bahwa lamanya perikatan audit antara KAP dan perusahaan paling lama selama 5 tahun berturut-turut.

Audit tenure diukur dengan menggunakan dummy. Perusahaan yang telah berganti Kantor Akuntan Publik (KAP) diberi kode 1, sedangkan perusahaan yang tidak berganti Kantor AKuntan Publik (KAP) diberi kode 0 .

\section{c. Rotasi Audit}

Rotasi Audit merupakan pergantian Akuntan Publik dimana Akuntan Publik di Indonesia hanya dapat mengaudit laporan keuangan perusahaan maksimal 3 (tiga) tahun berturut-turut. Variabel rotasi audit mengacu pada penelitian yang dilakukan oleh Siregar (2012) yaitu rotasi audit diukur dengan menggunakan variabel dummy yaitu nilai 1 jika terjadi rotasi auditor; nilai 0 jika tidak terjadi rotasi auditor.

\section{Metode Analisis Data}

Analisis data yang dilakukan dengan menggunakan analisis regresi logistik dan pengujian hipotesis dilakukan sesuai dengan rancangan pengujian hipotesis yang telah dibuat. Data diolah dengan menggunakan program IBM StatisticalPackage for Social Science (SPSS) versi 23.

\section{ANALISIS DAN PEMBAHASAN}

\section{Pengujian Hipotesis}




\section{a. Hasil Uji Parsial (Uji Wald)}

Hasil Uji Wald penelitian ini dapat dilihat pada tabel 2 berikut ini:

Tabel 2

Variables in the Equation

\begin{tabular}{|ll|r|r|r|r|r|r|}
\hline & & \multicolumn{1}{|c|}{ B } & \multicolumn{1}{c|}{ S.E. } & \multicolumn{1}{c|}{ Wald } & \multicolumn{1}{c|}{ Df } & \multicolumn{1}{c|}{ Sig. } & Exp(B) \\
\hline Step & FeeAudit & 2.421 & .795 & 9.266 & 1 & .002 & 11.252 \\
$1^{\mathrm{a}}$ & AuditTenure & 1.065 & 1.023 & 1.083 & 1 & .298 & 2.899 \\
& RotasiAudit & -.580 & 1.079 & .289 & 1 & .591 & .560 \\
& Constant & -54.295 & 17.733 & 9.374 & 1 & .002 & .000 \\
\hline
\end{tabular}

Sumber Data: Hasil Output SPSS

Berdasarkan tabel 2 di atas dapat dijelaskan pengujian hipotesis secara parsial sebagai berikut ini:

\section{1) Pengaruh Fee Audit Terhadap Kualitas Audit}

Variabel fee audit memiliki nilai signifikasi 0,02 lebih kecil dari 0,05. Berdasarkan hal tersebut dapat disimpulkan bahwa fee audit berpengaruh terhadap kualitas audit. Hasil ini konsisten dengan penelitian yang dilakukan oleh I Gusti Ngurah Indra Pramaswaradana dan Ida Bagus Putra Astika (2017), Maisyarah Salsabila (2018), dan Yuha Nadhirah Qintharah (2020). Hal ini menujukkan bahwa auditor yang berkualitas lebih tinggi akan mengenakan fee audit yang lebih tinggi pula, karena auditor yang berkualitas akan mencerminkan informasiinformasi yang dimiliki oleh pemilik perusahaan

\section{2) Pengaruh Audit Tenure Terhadap Kualitas Audit}

Variabel audit tenure memiliki nilai signifikasi sebesar 0,298 lebih besar dari 0,05. Berdasarkan hal tersebut dapat disimpulkan bahwa audit tenure tidak berpengaruh terhadap kualitas audit. Hasil ini konsisten dengan penelitian yang dilakukan oleh Yunike Nadya dan Pitaloka Santoso (2019), Tri Agustini dan Dian Lestari Siregar (2020). Hal menujukkan lamanya perikatan suatu KAP dengan klien tidak mempengaruhi independensi dan profesionalisme auditor dalam melaksanakan audit.

\section{3) Pengaruh Rotasi Audit Terhadap Kualitas Audit}

Variabel rotasi audit memiliki nilai signifikasi sebesar 0,591 lebih besar dari 0,05. Berdasarkan hal tersebut dapat disimpulkan bahwa rotasi audit tidak berpengaruh terhadap kualitas audit. Hasil ini konsisten dengan penelitian yang dilakukan oleh I Gusti Ngurah Indra Pramaswaradana dan Ida Bagus Putra Astika (2017), Maisyarah Salsabila (2018), Tri Agustini dan Dian Lestari Siregar (2020), dan Yuha Nadhirah Qintharah (2020). Hal ini menujukkan bahwa hubungan emosional antara klien dengan auditor yang disebabkan oleh lamanya hubungan antara auditor dengan kliennya, tidak mengurangi independensi auditor dalam melaksanakan audit. 


\section{b. Hasil Uji Simultan (Uji G)}

Uji Simultan dengan Uji G bertujuan untuk melihat seberapa besar pengaruh fee audit, audit tenure dan rotasi audit secara bersama-sama terhadap kualitas audit. Hasil Uji G dalam penelitian ini dapat dilihat pada tabel 3 berikut ini :

Tabel 3

Omnibus Tests of Model Coefficients

\begin{tabular}{|rl|r|r|r|}
\hline & & Chi-square & \multicolumn{1}{c|}{ df } & \multicolumn{1}{c|}{ Sig. } \\
\hline Step 1 & Step & 32.636 & 3 & .000 \\
& Block & 32.636 & 3 & .000 \\
& Model & 32.636 & 3 & .000 \\
\hline
\end{tabular}

Berdasarkan tabel 3 di atas, hasil signifikansi variabel fee audit, audit tenur, dan rotasi audit sebesar 0,000 lebih kecil dari 0.05. Hasil tersebut dapat disimpulkan bahwa variabel fee audit, audit tenure, dan rotasi audit berpengaruh secara bersama-sama terhadap kualitas audit.

\section{Analisis Regresi Logistik}

Berdasarkan Variables in The Equation Beta pada tabel 2 di atas, maka persamaan regresi logistik dari penelitian ini adalah sebagai berikut:

$$
\mathrm{Y}=\mathbf{- 5 4 , 2 9 5}+\mathbf{2 , 4 2 1} \mathrm{X}_{1}+\mathbf{1 , 0 6 5 \mathrm { X } _ { 2 } - 0 , 5 8 0 \mathrm { X } _ { 3 }}
$$

a. Nilai konstanta sebesar $-54,295$ yang berarti jika variabel fee audit, audit tenure, rotasi audit dianggap nol maka variabel kualitas audit sebesar 54,295 .

b. Koefisien regresi variabel fee audit diperoleh nilai sebesar 2,421 yang berarti jika variabel fee audit mengalami kenaikan 1 sementara variabel audit tenure dan rotasi audit diasumsikan tetap maka pengaruh kualitas audit juga akan mengalami kenaikan sebesar 2,421.

c. Koefisien regresi variabel audit tenure diperoleh nilai sebesar 1,065 yang berarti jika variabel audit tenure mengalami kenaikan 1 sementara variabel fee audit dan rotasi audit diasumsikan tetap maka pengaruh kualitas audit juga akan mengalami kenaikan sebesar 1,065.

d. Koefisien regresi variabel rotasi audit diperoleh nilai sebesar $-0,580$ yang berarti jika variabel rotasi audit mengalami kenaikan 1 sementara variabel fee audit dan audit tenure diasumsikan tetap maka pengaruh kualitas audit juga akan mengalami penurunan sebesar -0,580.

\section{Uji Koefisien Determinasi}

Hasil uji Koefisien Determinasi dapat pada tabel 4 berikut ini :

Tabel 4

Model Summary

\begin{tabular}{|l|r|r|c|}
\hline Step & -2 Log likelihood & $\begin{array}{c}\text { Cox \& Snell R } \\
\text { Square }\end{array}$ & $\begin{array}{c}\text { Nagelkerke R } \\
\text { Square }\end{array}$ \\
\hline 1 & $29,191^{\mathrm{a}}$ &, 516 &, 691 \\
\hline
\end{tabular}

Sumber Data : Hasil Output SPSS 
Tabel 4 di atas menunjukkan bahwa nilai Nagelkerke R Square adalah 0,691 atau 69,1\%. Ini berarti bahwa fee audit, audit tenure dan rotasi audit secara bersama-sama berpengaruh terhadap kualitas audit sebesar 69,1\% sedangkan sisanya sebesar 30,9\% dipengaruhi oleh variabel lainnya yang tidak termasuk dalam penelitian ini, misalnya ukuran perusahaan, reputasi KAP, ukuran KAP dan lain sebagainya.

\section{KETERBATASAN PENELITIAN}

1. Pada penelitian ini peneliti hanya memilih tiga variabel saja yaitu fee audit, audit tenure dan rotasi audit. Variabel-variabel lain seperti ukuran perusahaan, reputasi KAP, ukuran KAP dan lain sebagainya, mungkin dapat mempengaruhi kualitas audit.

2. Penelitian ini hanya terbatas pada perusahaaan manufaktur subsektor makanan dan minuman yang terdapat di Bursa Efek Indonesia, sehingga hasilnya tidak dapat digeneralisasikan untuk perusahaan- perusahaan lainnya yang terdaftar di BEI

3. Keterbatasan sampel penelitian hanya 45 sampel sehingga proses pengolahan data, analisis dan interpretasi hasil dianggap kurang, terutama dalam pengolahan data.

\section{KESIMPULAN}

1. Fee audit berpengaruh terhadap kualitas audit. Hal ini menujukkan bahwa bahwa auditor yang berkualitas lebih tinggi akan mengenakan fee audit yang lebih tinggi pula, karena auditor yang berkualitas akan mencerminkan informasi-informasi yang dimiliki oleh pemilik perusahaan

2. Audit tenure tidak berpengaruh terhadap kualitas audit. Hal ini menunjukkan lamanya perikatan suatu KAP dengan klien tidak mempengaruhi independensi dan profesionalisme auditor melaksanakan audit

3. Rotasi audit tidak berpengaruh terhadap kualitas audit. Hal ini menunjukkan hubungan emosional antara klien dengan auditor yang disebabkan oleh lamanya hubungan antara auditor dengan kliennya, tidak mengurangi independensi auditor dalam melaksanakan audit.

4. Fee Audit, Audit Tenure dan Rotasi Audit secara bersama-sama berpengaruh sebesar sebesar $69,1 \%$ terhadap kualitas audit, sedangkan sisanya sebesar $30,9 \%$ dipengaruhi oleh variable lainnya yang tidak termasuk dalam penelitian ini, misalnya ukuran perusahaan, reputasi KAP, ukuran KAP, dan lain sebagainya.

\section{SARAN}

1. Penelitian lebih lanjut disarankan untuk menambahkan variabel-variabel lain diluar variabel yang telah digunakan dalam penelitian ini, seperti ukuran perusahaan, reputasi KAP, ukuran KAP, dan lain sebagainya

2. Penelitian lebih lanjut diharapkan dapat memperluas tahun pengamatan atau daerah survey, sehingga hasil penelitian lebih mungkin untuk disimpulkan 
lebih luas.

3. Hendaknya penelitian selanjutnya lebih mempersiapkan waktu dalam melakukan penelitian empiris guna lebih meningkat perolehan data penelitian.

\section{DAFTAR PUSTAKA}

\section{Buku (Text Book)}

Agoes, S, 2014, Auditing: Petunjuk Praktis Pemeriksaan Akuntan Oleh Akuntan Publik. (E. Sri Suharsi, Ed) (4 ${ }^{\text {th }}$ Ed). Jakarta:Salemba Empat.

Arens A. Alvin, Randal J. Elder dan Mark S. Beasley. 2015, Auditing dan Jasa Assurance Pendekatan Terintegrasi. Jilid 1. Edisi Lima Belas-Jakarta. Erlangga.

Arens, Alvin., Randal J. Elder, Mark S. Beasley, 2011, Jasa Audit dan Assurance : Pendekatan Terpadu (Adaptasi Indonesia). dialih bahasakan oleh Amir Abadi Jusuf.Jakarta: Salemba Empat

Ghozali, I, 2016, Aplikasi Analisis Multivariet Dengan Program IBM SPSS 23. Edisi 8. Semarang: Penerbit Badan Penerbit Universitas Diponogoro.

Sugiyono, 2017, Metode Penelitian Kuantitatif, Kualitatif, dan R\&D. Bandung: Alfabeta, CV.

Tuanakotta, Theodorus M, 2011. Berpikir Kritis Dalam Auditing. Salemba Empat, JakartaWilliam F. Messier et al. 2014. Jasa Audit dan Assurance Pendekatan Sistematis. Jakarta: Salemba Empat

William F. Messier et al. 2014. Jasa Audit dan Assurance Pendekatan Sistematis. Jakarta: Salemba Empat

\section{Jurnal}

Ahmad Buchori dan Harry Budiantoro, 2019, Pengaruh Ukuran Perusahaan Klien, Audit Tenure, Dan Spesialisasi Auditor Terhadap Kualitas Audit, Jurnal Pajak, Akuntansi, Sistem Informasi, dan Auditing (PAKSI), Vol 1, No 1 (2019), Fakultas Ekonomi dan Bisnis, Universitas Yarsi, Jakarta

Andriani, Ninik., dan Nursiam 2018. "Pengaruh Fee Audit, Audit Tenure, Rotasi Audit Reputasi Auditor Terhadap Kualitas Audit”. (Studi Empiris Pada Perusahaan Manufaktur yang Terdaftar di Bursa Efek Indonesia Tahun 2013-2015)."Riset Akuntansi dan Keuangan Indonesia, Vol. 3 No. 1,pISSN: 1411-6510, e-ISSN: 2541-6111, Hal: 29-39, 2018.

Anton Eka Saputra. 2012. Pengaruh Kompetensi dan Independensi terhadap Kualitas Audit dengan Etika Auditor sebagai variabel moderasi. Journal usm. Vol 1 No. 2 Februari 2012. ISSN: 2301-9328.

Hartadi,Bambang. 2012. "Pengaruh Fee Audit, Rotasi KAP, dan Reputasi Auditor Terhadap Kualitas Audit di Bursa Efek Indonesia.” Jurnal Ekonomi dan Keuangan Indonesia Vol.16, No.1, pp. 84-103.

I Gusti Ngurah Indra Pramaswaradana dan Ida Bagus Putra Astika, 2017, Pengaruh Audit Tenure, Audit Fee, Rotasi Auditor, Spesialsiasi Auditor, Dan Umur Publikasi Pada Kualitas Audit, E-Jurnal Akuntansi, Vol.19.1. 
April (2017): 168-194, Fakultas Ekonomi dan Bisnis Universitas Udayana (Unud) Bali

Maisyarah Salsabila, 2018, Pengaruh Rotasi Kap Dan Fee Audit Terhadap Kualitas Audit Pada Perusahaan Sektor Keuangan Yang Terdaftar Di Bursa Efek Indonesia, Jurnal Riset Akuntansi Dan Bisnis, Vol 18, No 1 (2018), Fakultas Ekonomi dan Bisnis, Universitas Muhammaddiyah Sumatera Utara

Malem Ukur Tarigan dan Primsa Bangun Susanti, 2013, "Pengaruh Kompetensi, Etika dan Fee Audit terhadap Kualitas Audit".Jurnal Akuntansi

Margi Kurniasih dan Abdul Rohman, 2014, Pengaruh Fee Audit, Audit Tenure dan Rotasi Audit Terhadap Kualitas Audit

Nuratama, I Putu, 2011 . Pengaruh Tenur dan Reputasi Kantor Akuntan Publik Pada Kualitas Audit Dengan Komite Audit Sebagai Variabel Moderasi. Denpasar: Program Pasca Sarjana Universitas Udayana Denpasar.

Siregar, Amarullah, Wibowo dan Anggraita. 2012. "Aufit tenure, Auditor Rotation, and Audit Quality: The Case Of Indonesia." Asian Journal of Business and Accounting,pp.55-74.

Stefani Fransiska Lele Biri, 2019, Pengaruh Kompetensi, Independensi, dan Fee Audit Terhadap Kualitas Audit (Studi Kasus Kantor Akuntan Publik di Kota Yogyakarta), Akuntansi Dewantara Vol. 3 No. 2 Oktober 2019, Universitas Sarjanawiyata Tamansiswa Yogyakarta

Tri Agustini dan Dian Lestari Siregar, 2020, Pengaruh Fee Audit, Audit Tenure Dan Rotasi Audit Terhadap Kualitas Audit Di Bursa Efek Indonesia Periode 2014-2018, Jurnal EMBA, Vol.8 No.1 Februari 2020, Hal. 637 - 646, Program Studi Akuntansi, Universitas Putera Batam

Yuha Nadhirah Qintharah, 2020, Pengaruh Rotasi Audit, Kompleksitas Perusahaan Dan Fee Audit Terhadap Kualitas Audit Perusahaan Manufaktur Di Bursa Efek Indonesia, Juranal Ekonomi KIAT, Vol. 31 No. 1 (2020): Juni 2020, Fakultas Ekonomi Universitas Islam Riau

Yunike Nadya Pitaloka Santoso dan Tarmizi Achmad, 2019, Pengaruh Audit Tenure, Audit Fee, Tekanan Waktu, Tekanan Klien Dan Kompleksitas Tugas Terhadap Kualitas Audit Pada KAP Semarang, Diponegoro Journal Of Accounting, Volume 8, Nomor 4, Tahun 2019, Halaman 1-10.

\section{Referensi Lain}

Badan Pengawas Pasar Modal dan Lembaga Keuangan (BAPEPAM-LK), 2008,

Tentang Independensi Akuntan Yang Memberikan Jasa Di Pasar Modal

Institut Akuntan Publik Indonesia, 2016, Peraturan Pengurus No. 2 Tahun

2016 Tentang Penentuan Imbalan Jasa Audit Laporan Keuangan. IAPI

Kementrian Keuangan RI. Keputusan Menteri Keuangan Republik Indonesia

Nomor 20/2015. Tentang Jasa Akuntan Publik.

Republik Indonesia. 2015. Peraturan Pemerintah No. 20 Tahun 2015 Tentang

Praktik Akuntan Publik. Sekretariat Negara. Jakarta

http://www.idx.co.id/

Jurnal Ilmiah Akuntansi dan Ekonomi Volume. 6 Nomor. 2, Agustus 2021 Hal. 37 